\title{
China's Exchange Rate Impasse and the Weak U.S. Dollar
}

\author{
RONALD MCKINNON \\ GUNTHER SCHNABL
}

\begin{abstract}
CESIFO WORKING PAPER NO. 2386
CATEgORY 6: MONETARY POLICY AND INTERNATIONAL FINANCE

SEPTEMBER 2008
\end{abstract}
An electronic version of the paper may be downloaded
- from the SSRN website: Www.SSRN.com
- from the RePEc website: $\quad$ www.RePEc.org
- from the CESifo website: www.CESifo-group.org/wp




\title{
China’s Exchange Rate Impasse and the Weak U.S. Dollar
}

\begin{abstract}
Since 2004, China has been backed into a situation where the renminbi is expected to go ever higher against the dollar, and this one-way bet has led to a loss of domestic monetary control. Combined with a more general flight from the U.S. dollar, the resulting monetary explosion in China contributes to the worldwide increase in primary commodity prices-with excess liquidity reminiscent of the global inflation generated by the weak dollar in the 1970s.
\end{abstract}

JEL Code: E31, E61, F31.

Keywords: inflation, exchange rates, macro policies, current account imbalances.

\author{
Ronald McKinnon \\ Stanford University \\ Stanford, CA 94305-6072 \\ USA \\ mckinnon@stanford.edu
}

\author{
Gunther Schnabl \\ Leipzig University \\ Marschnerstrasse 31 \\ 04109 Leipzig \\ Germany \\ schnabl@wifa.uni-leipzig.de
}

August 8, 2008 


\section{Introduction}

Because China's trade surplus (net saving surplus) has spiraled up rapidly since 2000, its overall current-account surplus reached $\$ 360$ billion in 2007 . This covers almost half of the much larger U.S current-account deficit of $\$ 750$ billion - and if recent trends continue could cover more than half. Of course, this trade imbalance can only be corrected in the longer term if China's net saving-i.e., saving minus investment-falls, and the inverse occurs in the United States (the silver lining in the housing crisis?).

But, in the near term, China faces a financial conundrum. Because of political pressure from the United States, since July 21, 2005 the renminbi's peg to the dollar has crawled steadily upward at about 6 percent per year, and this rate of appreciation is expected to continue or even accelerate. Because of this one-way bet in the foreign exchange markets, since 2004 more than 100 percent of China's huge current account surplus has been financed by building up official exchange reserves.

Clearly, China with its ever-rising official exchange reserves contrasts sharply with other large surplus-saving countries such as Germany and Japan, whose surpluses on current account are matched by private short-term and long-term capital outflows. Could foreign exchange restrictions be the problem? By 2007, China had effectively eliminated foreign exchange controls on capital outflows by industrial corporations and financial institutions, while individuals have generous allowances for foreign travel. Although now free to diversify by investing outside of the country, the private (non state) sector refuses to do so. On the contrary, China's State Administration of Foreign Exchange (SAFE) is still struggling, somewhat vainly, to restrict the deluge of "hot" money inflows.

What is behind this abnormality? Because all participants in the foreign exchange markets now expect that the renminbi will continue appreciating against the dollar, they are reluctant to hold dollar assets. This reluctance is accentuated even more when American interest rates are abnormally low, as they now are with the U.S. Federal Funds rate at just 2 percent. So at this juncture in international finance, we distinguish between two meanings of the concept of "global imbalance". First, the great saving imbalances across countries that are reflected in the large trade (saving) deficit of the United States and large trade (saving) surpluses of China, Japan, Germany, oil exporters, and a host of smaller countries. Second, the further massive imbalance in financial intermediation for 
China's huge current account surplus with the United States. Instead of a "normal" outflow of private capital to finance China's trade surplus, China's central bank accumulates vast amounts of foreign exchange-some of which is invested in U.S. treasury bonds.

Of the two types of global imbalance, saving-investment imbalance across countries is at once the best known and most intractable in the short run. For 2007, figure 1 shows the huge net current account surplus of China amounting to over 10 percent of its GDP, and the large current account deficit of the United States of about 5 percent of its much larger GDP necessitating borrowing elsewhere around the world as well. However, re-balancing by reducing excess saving in the large creditor countries while increasing net saving in the United States is certainly possible in the longer run. And this international rebalancing can (best) be done without changing nominal exchange rates (McKinnon 2007a). Although very important, this global re-balancing of net saving propensities is intractable without being preceded by currency stabilization.

Figure 1: Saving-Investment Balance and Current Account, China and U.S.

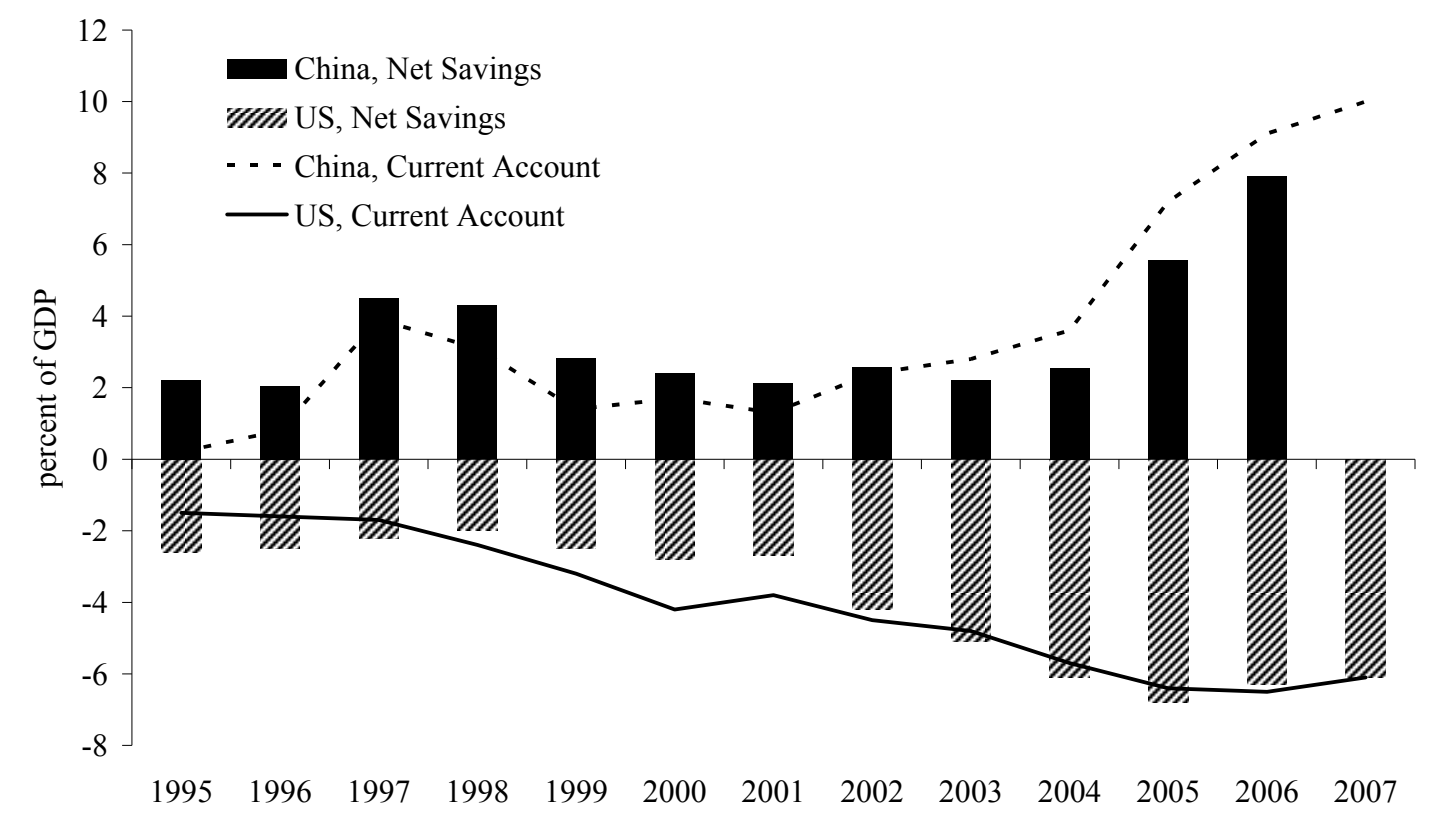

Source: IMF. 
Consequently, we initially focus on the sub-problem of unbalanced international financial intermediation and loss of monetary control in China. Because of the one-way bet on renminbi appreciation as aggravated by the extraordinary cuts in U. S. interest rates since August 2007, the People's Bank of China (PBC) has had to intervene massively to buy dollars with domestic base money. However, to better understand China's current monetary impasse, we first consider a brief history of China's foreign exchange policies since its market-oriented liberalization began in 1979.

\section{Three Phases of the Yuan-Dollar Exchange Rate}

At the risk of over simplifying, Figure 2 partitions the evolution of China's exchange rate regime into three phases: currency inconvertibility and exchange depreciation before 1994, the fixed dollar exchange rate from 1995 to 21 July 2005, and the subsequent appreciation by a predictable upward crawl through mid 2008:

Figure 2: Exchange Rate CNY/USD, 1980-2008

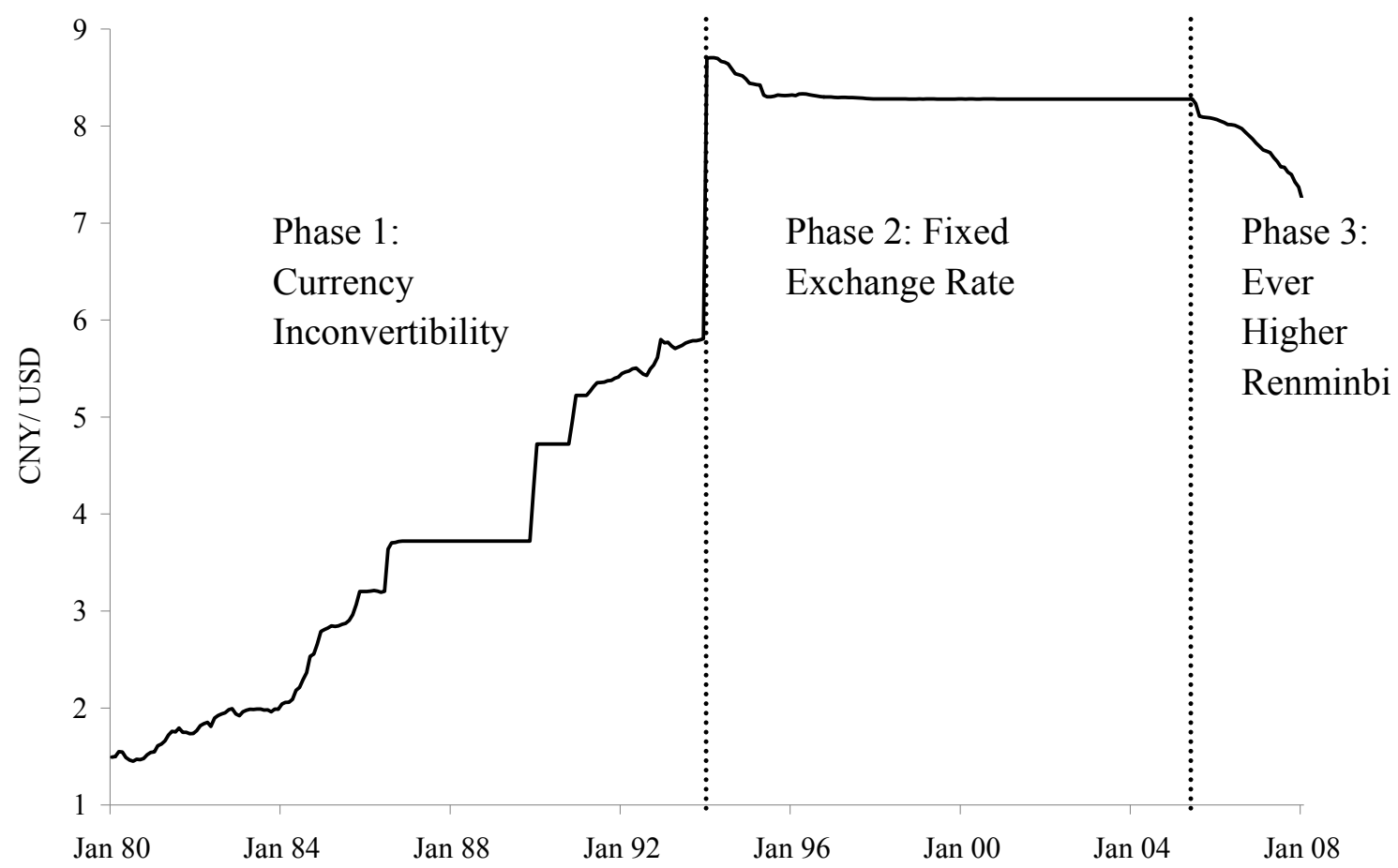

Source: IMF. 


\section{a. Phase 1}

Before 1994, China's currency was inconvertible in the strong sense of the word. There were multiple exchange rates (an official rate and floating swap rates for new exports of manufactures in different parts of the country), exchange controls on both current and capital account transactions, and both exports and imports had to be funneled through state trading companies. Throughout the 1980s, this so-called "airlock system" insulated domestic relative prices still influenced by central planning from those prevailing on world markets - except for a few fledgling Special Economic Zones (SEZs) on the East Coast.

So without free arbitrage between domestic and foreign prices, how the official exchange rate was set was arbitrary. Figure 2 shows only the official exchange rate's path from only 1.5 yuan per dollar back in 1979 and increased (devalued) in steps to 5.8 yuan per dollar by the end of 1993. However, the incentives for exporting or importing were not much affected-nor was the domestic price level. And tight exchange controls prevented "hot" money flows. The official rate was not economically very meaningful.

\section{b. $\quad$ Phase 2}

1994 was China's banner year for sweeping financial reforms both in domestic taxation and in the organization of foreign trade. The Chinese authorities abolished exchange controls on current-account transactions (exporting, importing, interest and dividends) and unified the exchange rate. Separate and more favorable exchange rates for manufactured exports were abolished. By 1996, China had formally satisfied the International Monetary Fund's Article VIII on current account convertibility.

The new consolidated official rate was set at 8.7 yuan per dollar in 1994, which was closer to the average of the previous swaps rates. True, this represented a substantial devaluation of the official rate from 5.8 yuan per dollar, but the period 1993-95 was a period of high inflation in China. Figure 3 shows that the nominal depreciation of the official rate was about the same order of magnitude of the excess of China's inflation over that prevailing in the United States (as much as 20 percent in 1994). With the currency unification, real depreciation - if any — was minimal. 
Figure 3: CNY/USD Exchange and China-U.S. Inflation Differential

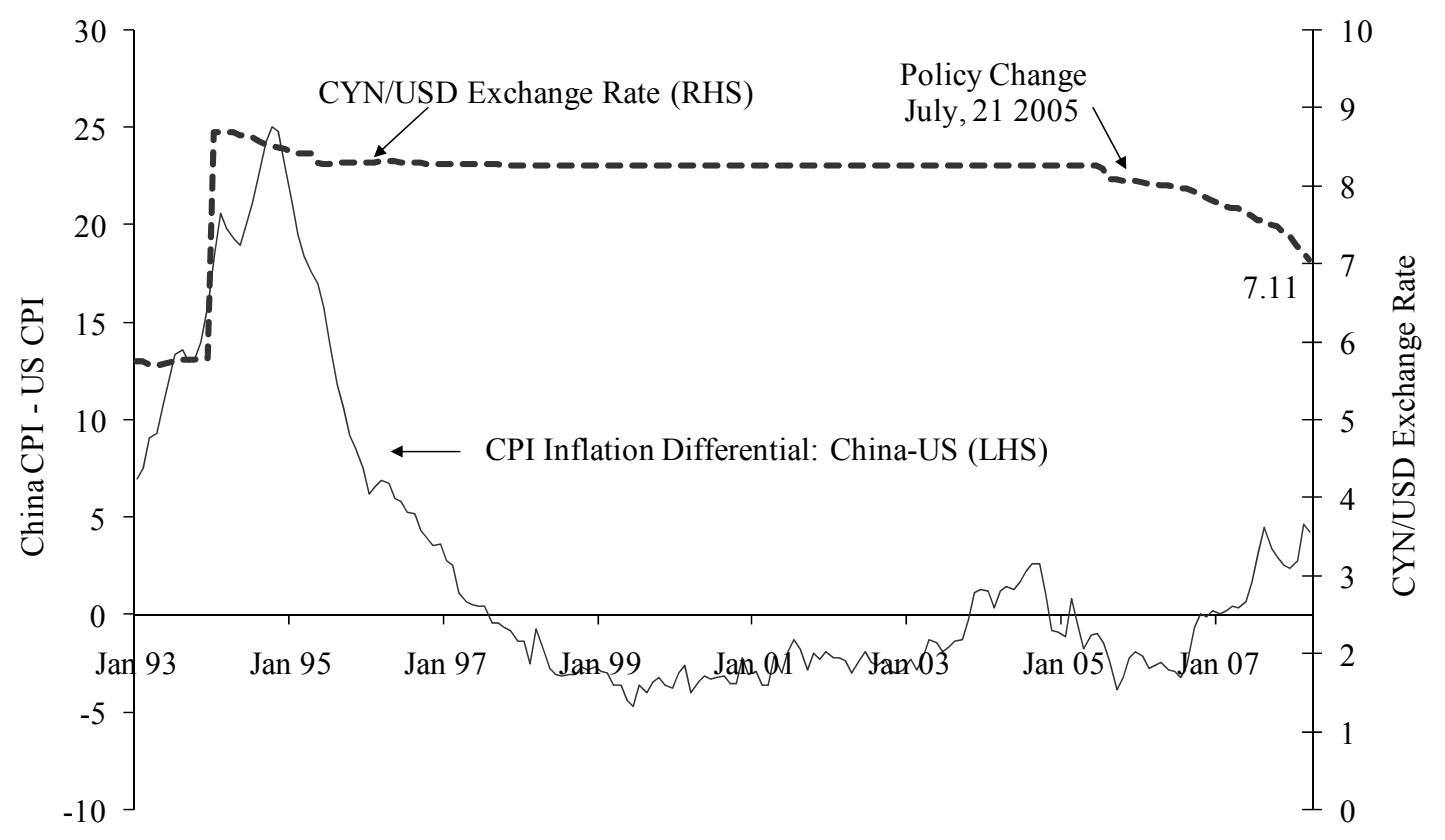

Source: IMF.

By 1995, the nominal exchange rate had settled down to about 8.28 yuan per dollar and was held there for 10 years - our Phase 2. The main motivations for so fixing the exchange rate were two fold. First, in the previous phase of currency inconvertibility going back to 1979 when liberalization began, China had suffered from a "roller coaster" ride in the rate of real output growth and in inflation rates-peaking out with the high inflation of 1993-95 (Figure 4). With only an embryonic domestic capital market and with the progressive relaxation of central planning and direct price controls, the PBC had great trouble anchoring the overall price level by domestic means alone. Thus the unification of the exchange rate regime in 1994, and move to full current account convertibility 1994-96, presented an opportunity to adopt a more stable external nominal anchor. And Figure 4 shows that, as the exchange rate remained fixed at 8.28 yuan/dollar until 21 July 2005, cycles of inflation and real output growth in China were smoothedwhile inflation came down to the American level by 2004 . 
Figure 4: Real GDP Growth and Consumer Price Inflation, China, 1980-2007

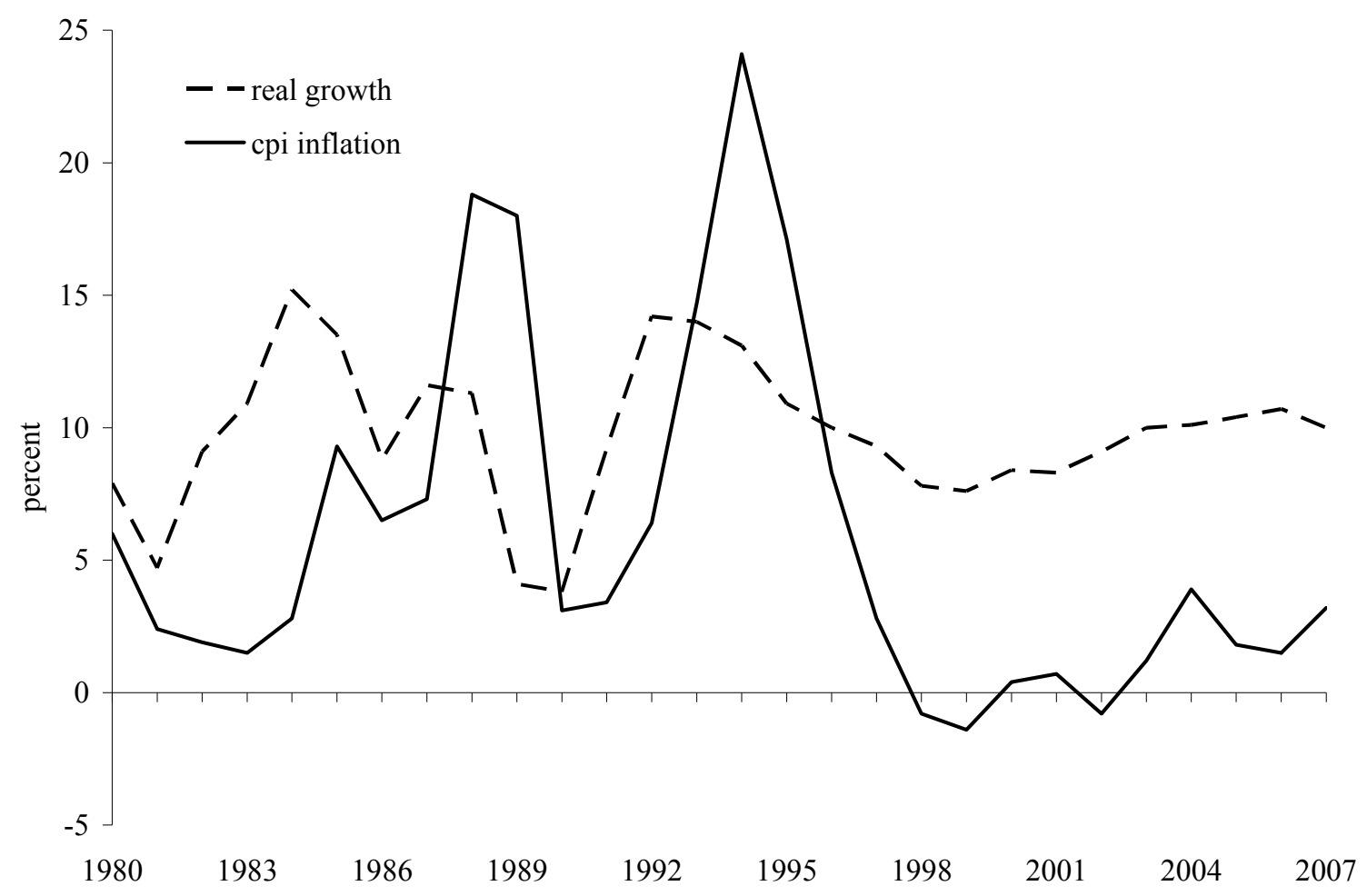

Source: IMF.

Indeed, in the great Asian crisis of 1997-98, sharp devaluations by neighboring countries - not only the well known crisis five ${ }^{1}$, but also by Japan, Taiwan, and Singapore - imposed strong deflationary pressure on China. But Premier Zhu Rongji wisely ignored advice to let the renminbi become more "flexible" and depreciate in tandem. Instead, he held on to the fixed exchange rate anchor and engaged in a great "one trillion" dollar fiscal expansion, largely infrastructure investments, over the next four years. In the crisis, China's exchange rate and fiscal policies saved the East Asian economy from further imploding - and allowed the neighboring countries to recover more quickly. China's policy of fixing the nominal exchange rate at 8.28/dollar, within a narrow band of \pm .3 percent for daily fluctuations, gained credibility.

\footnotetext{
${ }^{1}$ Indonesia, Korea, Malaysia, Philippines, and Thailand.
} 
Table 1: Foreign Reserve Holdings and Base Money of the PBC, 1990-2007

\begin{tabular}{|c|c|c|c|c|c|c|}
\hline & Reserves & $\begin{array}{l}\text { Base } \\
\text { Money }\end{array}$ & $\begin{array}{c}\text { Reserves } \\
\text { Base } \\
\text { Money }\end{array}$ & $\begin{array}{c}\Delta \\
\text { Reserves }\end{array}$ & $\begin{array}{l}\Delta \text { Base } \\
\text { Money }\end{array}$ & $\begin{array}{c}\Delta \text { Reserves/ } \\
\Delta \text { Base Money }\end{array}$ \\
\hline 1990 & 82.0 & 638.7 & $12.8 \%$ & 41.5 & 147.6 & $28.1 \%$ \\
\hline 1991 & 140.0 & 793.1 & $17.6 \%$ & 57.9 & 154.4 & $37.5 \%$ \\
\hline 1992 & 133.0 & 922.8 & $14.4 \%$ & -6.9 & 129.7 & $-5.3 \%$ \\
\hline 1993 & 155.0 & 1314.7 & $11.8 \%$ & 21.9 & 391.9 & $5.6 \%$ \\
\hline 1994 & 445.1 & 1721.8 & $25.9 \%$ & 290.2 & 407.1 & $71.3 \%$ \\
\hline 1995 & 667.0 & 2076.0 & $32.1 \%$ & 221.8 & 354.2 & $62.6 \%$ \\
\hline 1996 & 956.2 & 2688.9 & $35.6 \%$ & 289.3 & 612.9 & $47.2 \%$ \\
\hline 1997 & 1345.2 & 3063.3 & $43.9 \%$ & 389.0 & 374.4 & $103.9 \%$ \\
\hline 1998 & 1376.2 & 3133.5 & $43.9 \%$ & 31.0 & 70.3 & $44.1 \%$ \\
\hline 1999 & 1485.8 & 3362.0 & $44.2 \%$ & 109.6 & 228.5 & $48.0 \%$ \\
\hline 2000 & 1558.3 & 3649.2 & $42.7 \%$ & 72.5 & 287.2 & $25.3 \%$ \\
\hline 2001 & 1986.0 & 3985.2 & $49.8 \%$ & 427.8 & 336.0 & $127.3 \%$ \\
\hline 2002 & 2324.3 & 4513.8 & $51.5 \%$ & 338.3 & 528.7 & $64.0 \%$ \\
\hline 2003 & 3114.2 & 5284.1 & $58.9 \%$ & 789.9 & 770.3 & $102.5 \%$ \\
\hline 2004 & 4696.0 & 5885.6 & $79.8 \%$ & 1581.8 & 601.5 & $263.0 \%$ \\
\hline 2005 & 6344.0 & 6434.3 & $98.6 \%$ & 1648.0 & 548.7 & $300.3 \%$ \\
\hline 2006 & 8577.3 & 7775.8 & $110.3 \%$ & 2233.3 & 1341.5 & $166.5 \%$ \\
\hline 2007 & 12217.1 & 9243.3 & $132.2 \%$ & 3639.8 & 1467.5 & $248.0 \%$ \\
\hline
\end{tabular}

Source: IMF, OECD. Billion CNY.

In Phase 2, the fixed exchange rate's success as an anchor for China's price level was as much a guideline for domestic monetary policy as an instrument. True, continual PBC purchases of foreign exchange, modest by today's standards, were the main instrument for increasing the monetary base. However, before 2004 when the renminbi was not expected to appreciate, these purchases generally amounted to less than 100 percent of the growth in base money (Table 1). Thus substantial sterilization operations were not necessary. In this fixed rate period, the rapid increase in the demand for base money from China's very high GDP growth, coupled with an income elasticity of money demand greater than one, more or less balanced the rapid increase in money supply.

However, the monetary control mechanism was not only the exchange-rate itself. To prevent overheating, there remained a panoply of supporting direct controls over bank credit - including reserve requirements, credit quotas, lending restrictions by sector, and 
so on. But for controlling inflation, the renminbi's exchange rate against the dollar was the effective intermediate target

Why didn't China rely more heavily on domestic financial indicators? With rapid financial transformation and very high saving, the velocity of money-whether defined by M1, M2, or M3 - was (is) too unpredictable for any monetary aggregate to be useful as an intermediate target. And the velocity of money, defined as GDP/M, becomes even more difficult to predict when nominal GDP itself is subject to large revisions. Indeed, nominal GDP was revised sharply upward in 2006. Although Figure 5 shows that M2 still grew much faster than nominal GDP, the authorities could have no firm idea of what was "too fast" and thus inflationary.

\section{Figure 5: Broad Money (M2) and Nominal GDP, China, 1990-2007}

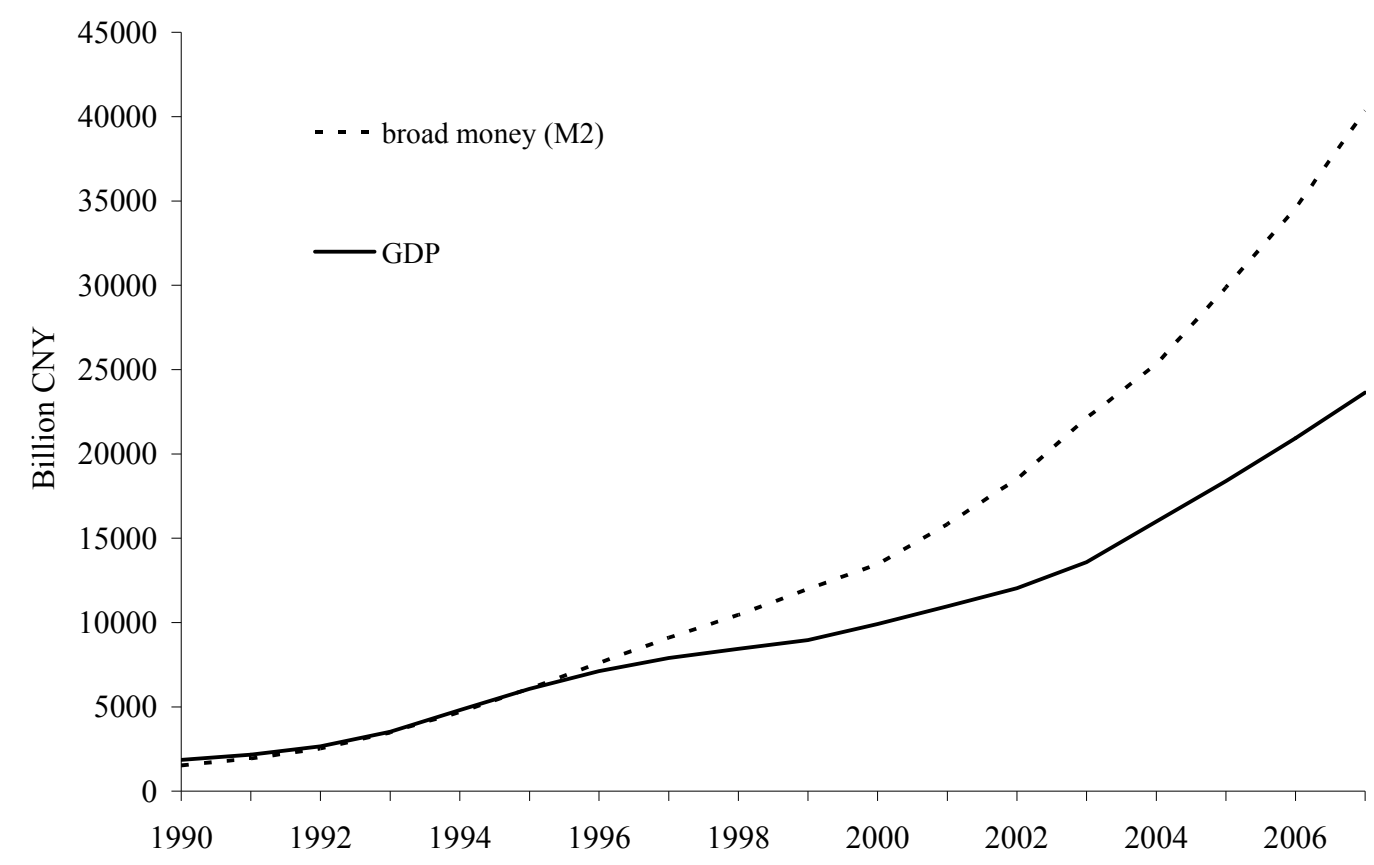

Source: OECD, WEO.

Still, couldn't the Chinese monetary authorities target inflation more directly? The absence of a well developed domestic bond market, and presence of rigid interest rate pegs for bank deposits and loans, militated against using conventional open-market operations to target some key internal interest rate-as per the Taylor Rule - to control 
the macro economy as in the United States or euro area. The "New Keynesian" Taylor Rule itself presumes that the authorities have fairly accurate information on the ebb and flow of excess capacity over the business cycle, which could not be the case in China's era of extremely high — but somewhat unpredictable real-economic growth. Thus, the fixed dollar exchange rate was the preferred intermediate monetary target for stabilizing the price level. In Japan's similar era of extraordinary real economic growth and financial change from 1949 to 1971 , the domestic price level was safely anchored by pegging the yen at 360 to the dollar (McKinnon and Ohno, 1997).

To summarize Phase 2, the 10-year fix at 8.28 yuan per dollar was seen as a way of implementing monetary policy, made possible by the currency unification in 1994 and the move to current account convertibility in 1994-96. It was very successful in anchoring the domestic price level through 2004 (Figure 3) and smoothing fluctuations in real economic growth (Figure 4). Contrary to what is often alleged ${ }^{2}$, the fixed exchange rate was not a device to cunningly "undervalue" the renminbi so as to create a mercantile advantage by artificially stimulating exports.

\section{c. Phase 3}

What then pushed China off its fixed-rate anchor on July 21, 2005?

First, after 2003, unexpected current account surpluses, coupled with large inflows of foreign direct investment led to balance of payments surpluses. Figure 1 shows the sudden spurt in China's multilateral current account surplus from 2 percent of GDP in 2003 to more than 10 percent in 2007. (In Japan's high growth era of the 1950s and 60s under a fixed exchange rate, significant inflows of FDI had been prohibited and domestic saving and investment were in better balance.) And the U.S. was the recipient of much of China's surge in manufactured exports. China's bilateral trade surplus with the United States (Figure 6), reached $1.1 \%$ of America's GDP in 2006-twice as large as Japan's. The loss of jobs in U.S. manufacturing disturbed American politicians.

2 See, for example, Dooley, Folkerts-Landau and Garber 2004 for misinterpreting China's fixed exchange rate, and those of smaller Asian countries, as a more or less deliberate attempt to undervalue their currencies. 
Figure 6: Bilateral Trade Balances of Japan and China versus the U.S. (percent of U.S. GDP)

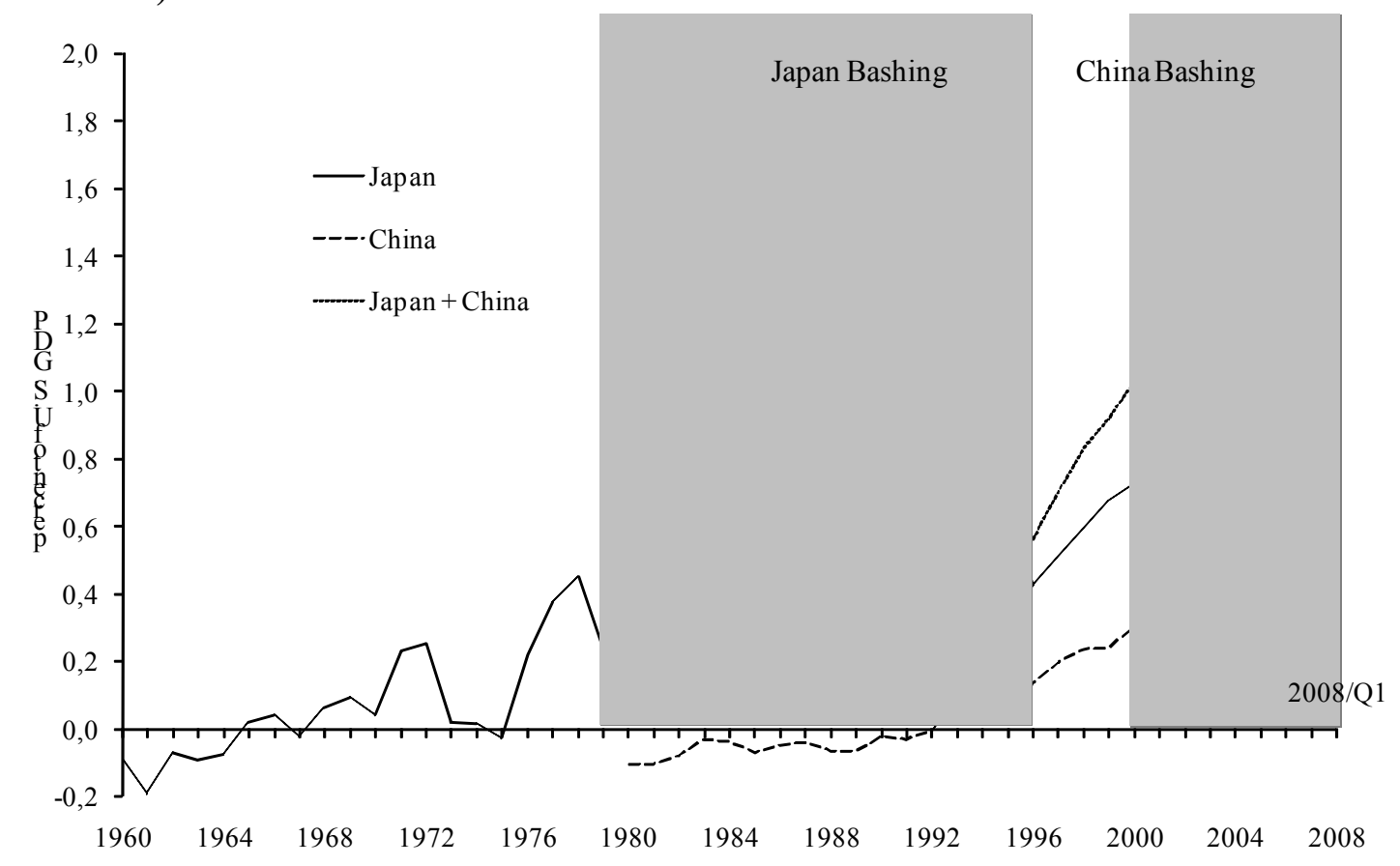

Source: IMF.

Second, China's balance of payments surpluses were misinterpreted by economists and politicians everywhere as an exchange rate problem, i.e., the renminbi was artificially "undervalued". And the more rapid build-up of official exchange reserves in 2003-5 (Table 1), was taken as per se evidence of unfair currency manipulation. Whence the American political pressure on China to begin appreciating the renminbi: our Phase 3. Led by Senators Charles Schumer of New York and Leslie Graham of North Carolina, the U.S. government threatened to sanction China by imposing import tariffs unless it appreciated. And on July 21, 2005 it appreciated discretely by 2.5 percent, and subsequently has been appreciating by about 6 percent per year with the disruptive effects on international capital flows discussed above.

The expectation of further appreciation of the renminbi coupled with the sharp fall in U.S. interest rates, the Federal Funds rate fell from 5.25 percent August 2007 to just 2 percent in mid 2008, have become the crucial determinants of the huge accumulation of official exchange reserves in China-Table 1, Figure 7, and Figure 8. Despite massive 
sterilization efforts by the PBC to prevent the monetary base from exploding, inflation could not be fully contained.

Figure 7: Foreign Reserves of China, Japan, Germany, and U.S., 1990-2007

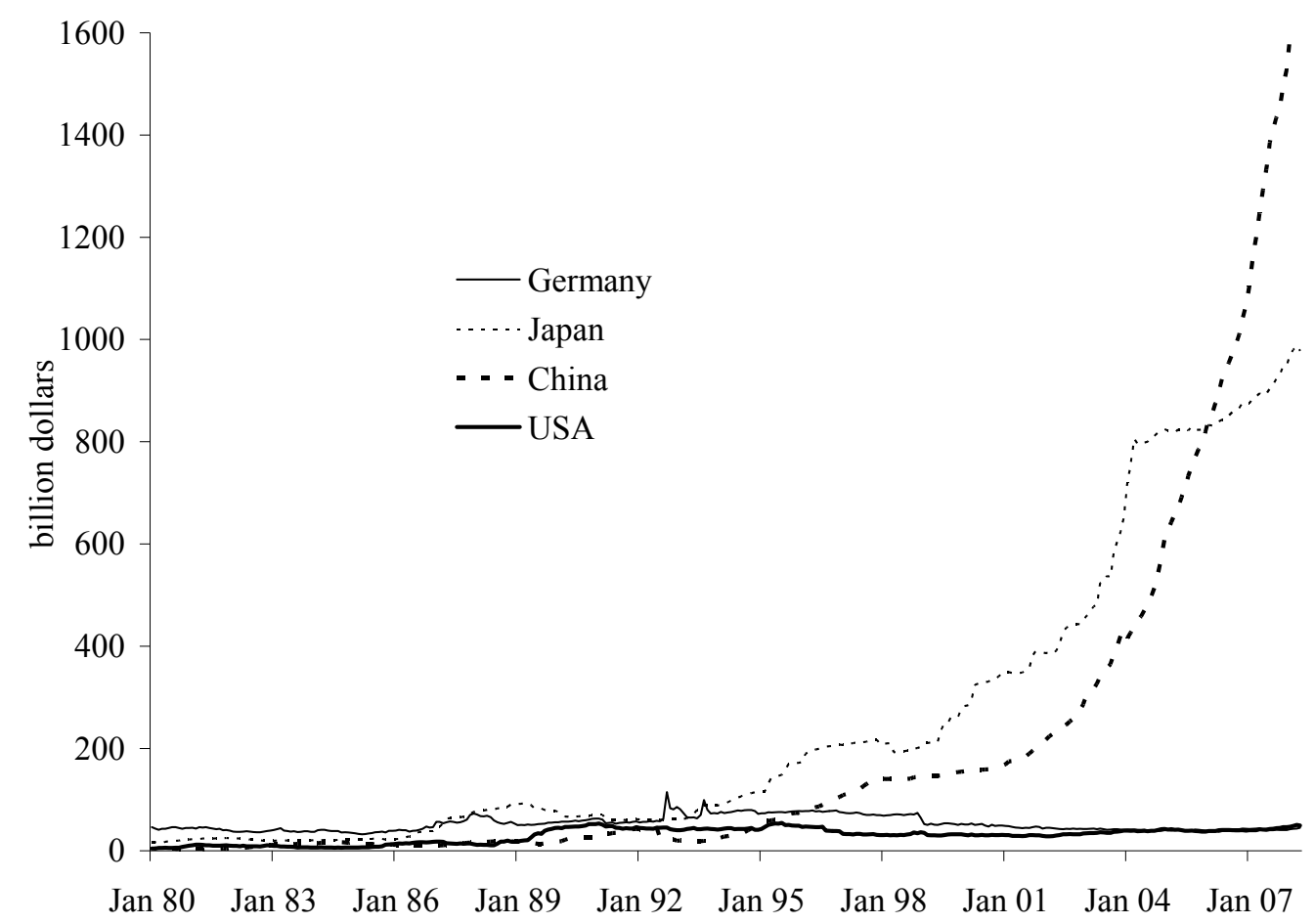

Source: IMF, Peoples Bank of China.

Figure 9 shows that consumer price inflation in China increased in 2004 with low U.S. interest rates, but then fell in 2005-06 when U.S interest rates rose so as to reduce capital inflows into China. However, after August 2007 when U.S. interest rates started to decline again, the inflationary outlook for China and the world changed dramatically. Official reserve accumulation further accelerated, raw material and food prices soared, and monetary growth in China became increasingly difficult to contain by various sterilization measures. By May 2008, Chinese consumer price inflation had climbed above $8 \%$ (Figure 9 ). 
Figure 8: Balance of Payments, China, 1990-2007

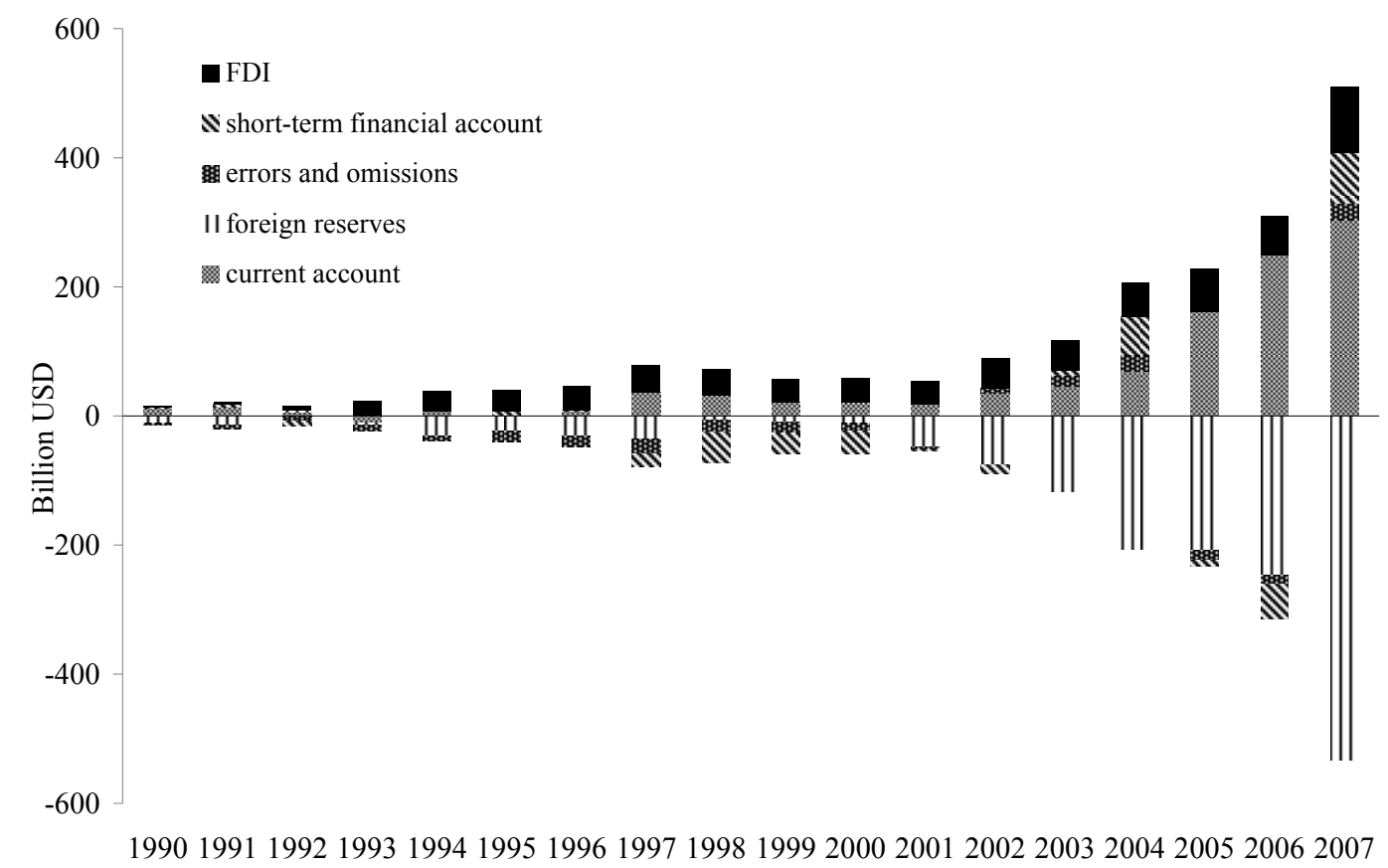

Source: IMF, SAFE. 2007 approximated.

With domestic consumer prices rising, Chinese wage increases are putting additional upward pressure on the international dollar prices for Chinese manufactures. By 2007-08, China had been transformed from being a deflationary force on the world economy into an inflationary one. The combination of internal inflation and an appreciating renminbi is now raising the dollar prices of Chinese manufactured goods shipped to the United States. Before 2007, Figure 10 shows the (slightly) falling dollar prices of goods imported from China that helped to keep U.S. and world inflation surprisingly low for some years - sometimes known as the "great moderation". By 2007-08, however, the figure shows the dollar prices of Chinese goods shipped to the U.S. spiking upward. Combined with loose monetary policy in the United States, the center country under the world dollar standard, worldwide inflation has been unleashed. 
Figure 9: Inflation, China and U.S., 1998-2008

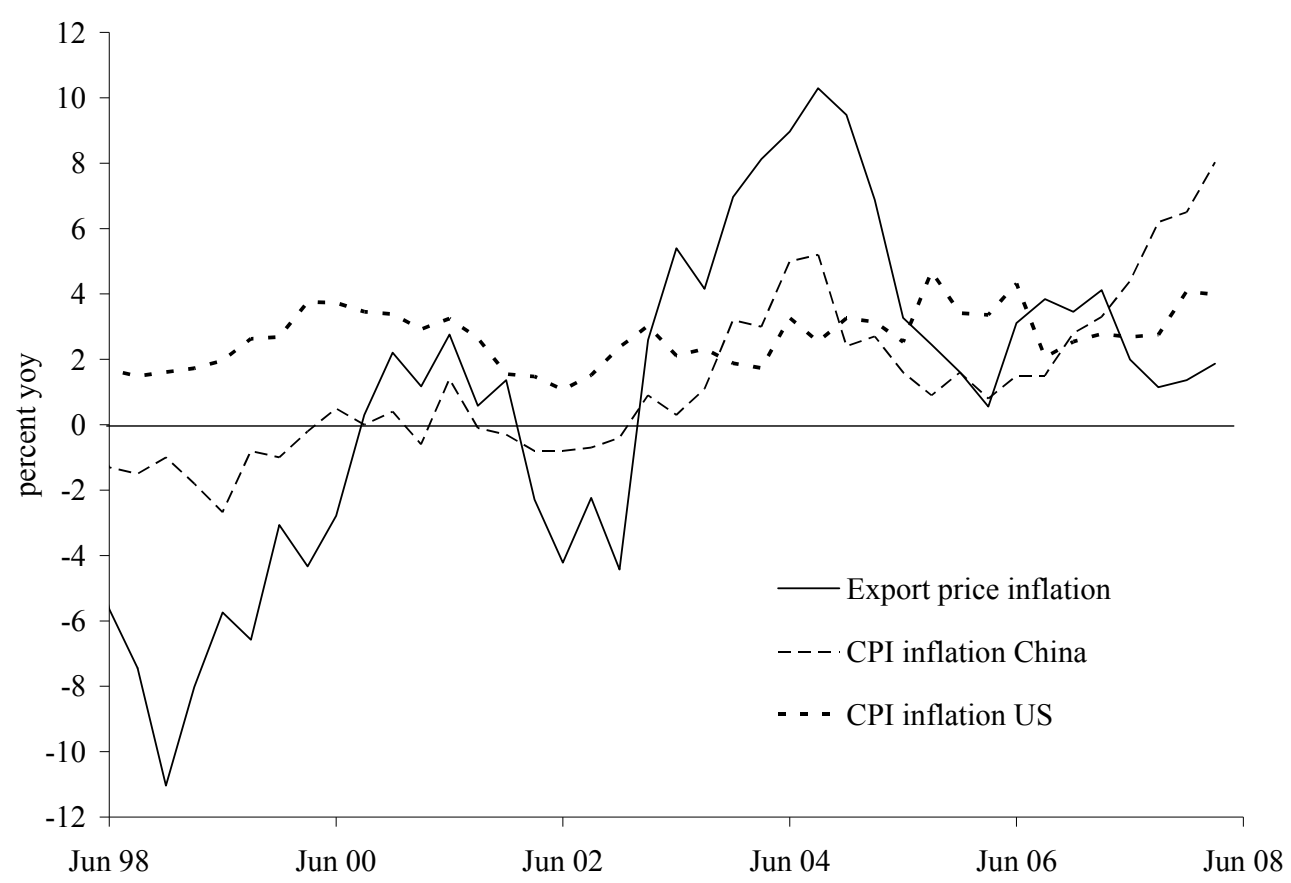

Source: Ecowin Database.

True, even without internal inflation, China's rapid growth could well have bid up the prices of primary products - food, oil, and industrial raw materials. However, the loss of monetary control in "peripheral" economies - not only in China but in other emerging markets - accentuates the demand for primary products. As in the 1970s, behind this worldwide inflationary pressure is (was) unduly loose monetary policy by the United States coupled with American attempts to devalue the dollar for mercantilist reasons. The resulting capital flight from the United States leads emerging markets into overly expansionary monetary policies as they try to resist appreciation of their individual currencies (Swoboda 1978, McKinnon 1981, Hoffman and Schnabl forthcoming). However, the collective effect is undue monetary expansion in the world as a whole ${ }^{3}$ with inflation that eventually rebounds back on the United States itself.

\footnotetext{
${ }^{3}$ Notice that when Alexander Swoboda was writing about the dollar's standard's inflationary transmission mechanism in the late 1970s, the important "peripheral" countries forced into undue monetary expansion were in Western Europe and Japan. But now the strong euro system has curbed European monetary expansion and Japan is mired in a near-zero interest rate liquidity trap. So the main avenues of excess "world" money creation are in individual Asian countries outside of Japan.
} 
Figure 10: U.S. Price Inflation over Imports from China, 2005-2008

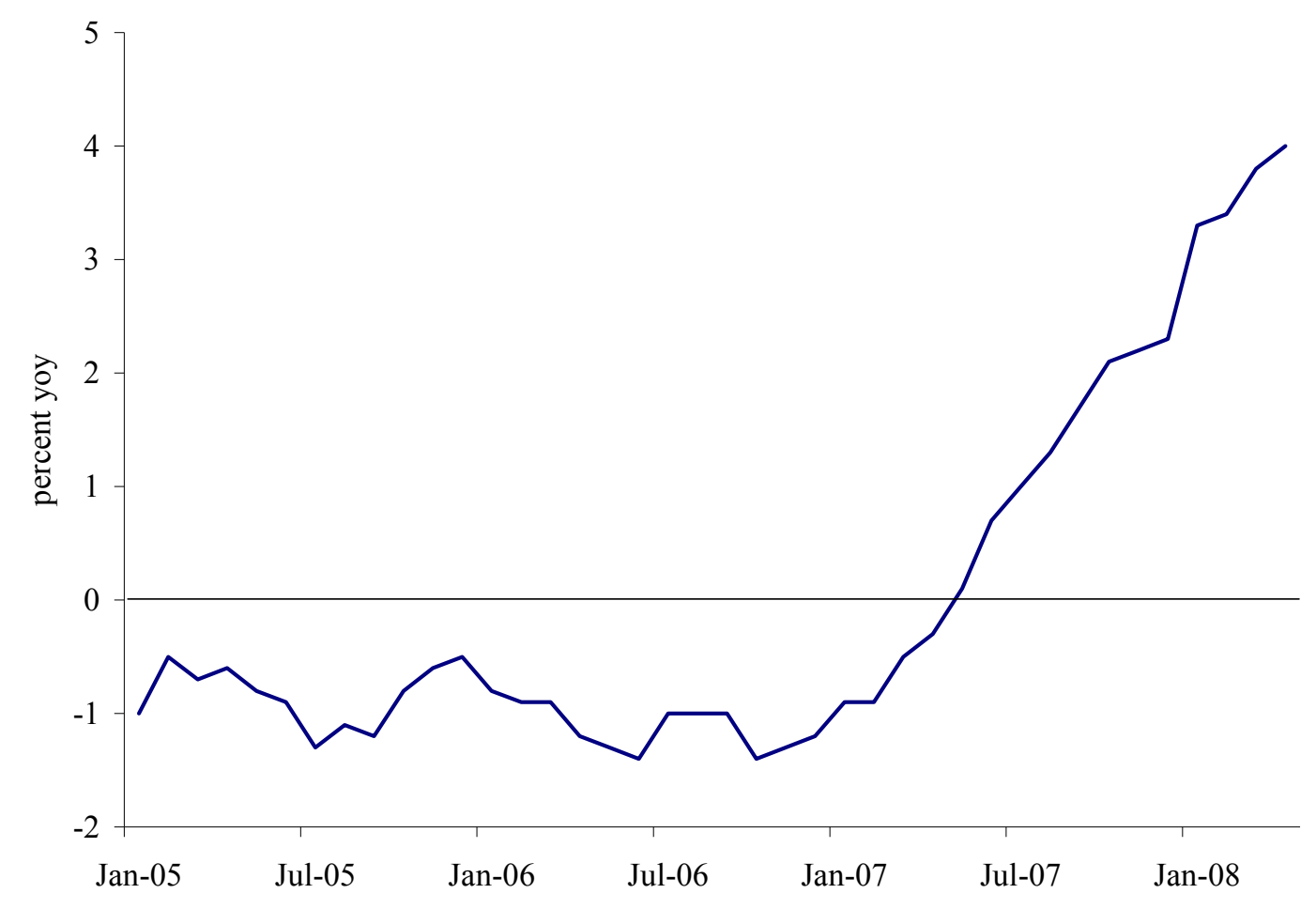

Source: Ecowin Database.

\section{Overcoming Three Misconceptions about Currency Stabilization}

Because China's current monetary and exchange rate impasse-with its one-way bet in the foreign exchange markets - is overheating its economy with unwanted inflation, its government is inhibited from taking appropriate actions to reduce its ballooning net trade (saving) surplus. Obvious steps for reducing "excess" net saving - such as cutting taxes and increasing government social expenditures would have a near-term inflationary impact. Less obvious is the impact on net saving of forcing (or encouraging) much higher dividend payouts from China's corporate sector; but, under certain conditions, that too could be expansionary.

Meanwhile, China's current account surplus, uncovered by outflows of private capital, continually worsens the monetary impasse. Figure 11 shows the recent "frenzied" build up of exchange reserves so far in 2008 reaching US\$100 billion per month, which is much higher than the monthly trade surplus. Because foreigners misinterpret the trade 
surplus and accumulating official exchange reserves to be evidence of an undervalued currency, they call for further appreciation of the renminbi. This foreign pressure strengthens the expectation that the renmimbi will be higher in the future, thus causing more inflows of hot money.

Figure 11: Monthly Foreign Reserve Build-Up, China, 1999-2008

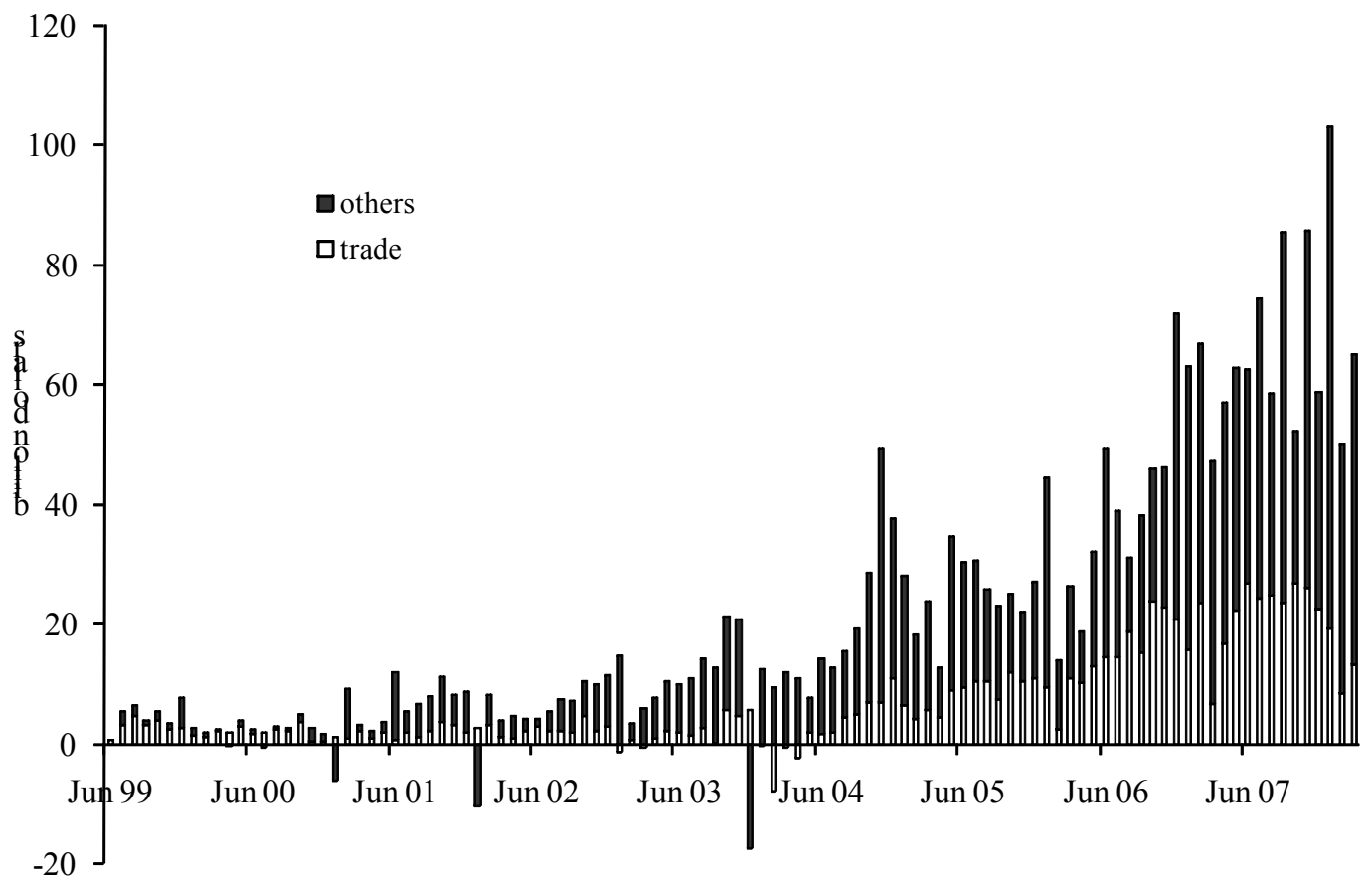

Source: IMF. Black and white areas indicate overall per month reserve accumulation. White areas indicate the Chinese monthly trade balance.

What is the best way to escape from this conundrum? China can't end its exchange rate impasse, and the worldwide monetary turmoil that goes with it, on its own. With proper foreign cooperation, however, the monetary impasse from the one-way bet in the foreign exchange markets could be resolved rather quickly. Thus, currency stabilization should precede measures to correct the saving-investment imbalance-which may take months or years to be effective both in China and abroad.

Nevertheless, to be successful, the political economy of any international agreement likely requires both as a package deal. China bashing to get the renminbi up can only be stopped if China proposes definite fiscal measures to reduce its future saving 
surpluses-possibly in conjunction with U.S. efforts to reduce America's saving deficiency, and overly loose domestic monetary policy leading to a weak dollar.

Populist politics aside, what inhibits China and the United States (representing the interests of the industrial economies more generally) from agreeing on such a package deal that would be of such great mutual benefit? Three common misconceptions in economic theory on the role of the exchange rate inhibit any political agreement to stabilize China's currency. Let us consider each in turn

\section{Misconception \#1: The exchange rate can affect the trade balance.}

Many, if not most, economists believe that a country's net trade balance can be controlled by manipulating the level of its exchange rate. However, a current account surplus (dominated by a trade surplus) just reflects a surplus of saving over investment at homeand the converse abroad. Thus, how a discrete appreciation of a creditor country's currency will eliminate its saving surplus is neither obvious nor unambiguous. True, its goods would become more expensive to foreigners - the relative price effect. But, in an economy open to international capital flows, domestic investment would fall because appreciation makes the country a more expensive place in which to produce. Also, because China owns huge stocks of foreign currency claims (largely dollars), a negative wealth effect from having the dollar fall against the renminbi would further reduce domestic expenditures-including for imports. This decline in imports offsets the dampening effect of higher foreign currency prices for exports so as to leave any change in the net trade balance small and ambiguous (Qiao 2007).

To illustrate this exchange rate-trade balance misconception, it is instructive to revisit the consequences of Japan bashing to get the yen up more than three decades earlier starting with the Nixon shock of August 1971. The yen rose episodically from 360 to the dollar in early 1971 to touch 80 to the dollar in April 1995. "Despite" this enormous cumulative appreciation, Japan's net trade surplus rose from being negligible in the 1960s to average about 2 percent of GDP in the 1970s, peaked out at about 5 percent in the late 1980s, and remains close to four percent of GDP in 2008 with the yen at 100-110 to the dollar. Massive currency fluctuations had no systematic impact on Japan's net trade (saving) balance. 
However, the great nominal appreciations of the yen against the dollar, which Japan more or less welcomed during the worldwide inflation of the 1970s, eventually unhinged Japan's macro economy (McKinnon and Ohno 1997). In the late 1980s, the syndrome of the ever-higher yen provoked bubbles in Japan's stock and land markets along with a falling WPI (Hoffmann and Schnabl forthcoming). When the bubbles broke in 1990-91 followed by a further sharp rise in the yen in 1994-95, Japan was thrown into deflationary slump: its infamous "lost decade" of 1992 to 2002. Foreign exchange risk created (and still sustains) a near zero interest liquidity trap that renders monetary policy virtually impotent for stimulating domestic spending. (Goyal and McKinnon, 2003). Although Japan has had modest export-led GDP annual growth of 2 to 3 percent since 2002, a deflationary hangover continues: wages and per capita consumption are stagnant (McKinnon, 2007b).

\section{Misconception \#2. Ongoing exchange rate appreciation reduces inflation}

The second, but more subtle, misconception is that ongoing exchange appreciation can reduce domestic price inflation - or, at the very least, insulate the economy from international inflation. China gets much gratuitous advice to appreciate faster in order to "fight inflation". This admonition is certainly true in the long run, as Japan's unfortunate experience with eventual deflation from yen appreciation attests. However, for a country emerging from a fixed nominal exchange rate where domestic and foreign rates of price inflation had been more or less aligned, the near-term effect of a well-telegraphed transition to an appreciating currency can be highly inflationary-as with China's current monetary impasse. In the near-term transition, the inflationary impact from the loss of monetary control can overwhelm the deflationary impact of a higher level of the exchange rate.

Again, let us refer to Japan's earlier experience with this transition problem. Under the Bretton Woods system of fixed exchange rate parities, the yen had been successfully fixed at 360 to the dollar from 1949 to August 1971, so that price inflation in tradable goods (WPI) between the U.S. and Japan were similar. As early as 1970, however, market participants began to project that the dollar might be depreciated. Hot money began to flow out of the United States into European countries as well as Japan 
(despite its capital controls). In order to prevent more precipitate appreciation, in 1971-72 the Bank of Japan intervened heavily in the foreign exchange markets with a rapid buildup of foreign exchange reserves and surge in domestic money growth. By 1974, annualized WPI inflation in Japan became higher than in the United States: 31.3 percent versus "just" 18.9 percent in the U.S. Only in the late 1970s did Japanese inflation fall below American - the "long run" relative deflationary effect of a higher yen that most economists expect. But the length and strength of the near term inflationary transition was surprising. China is still in the inflationary "near-term" which, with no change in present circumstances of arm twisting to get the renminbi up, could continue for an uncomfortably long time.

Are there circumstances where China should acquiesce to continual reminbi appreciation? Clearly if the center country under the world dollar standard continues to inflate too much, the People's Bank of China would have little choice but to acquiesce to a managed ongoing appreciation of the renminbi against the dollar. However, the current rate of appreciation is too rapid for securing either near-term monetary control in China or long-term price-level alignment with the United States.

Misconception \# 3. Floating the rate would equilibrate the foreign exchange market.

"Flexibility" is a nicer word than floating. Couldn't the PBC simply withdraw from the foreign exchange market and let the exchange rate be determined by private market makers - much in the way that the euro's value against the dollar is determined? No, because this proposed solution presumes that a determinate market exchange ratewhich could balance the demand and supply of dollars in terms of renminbi-actually exists if the PBC were to exit the market. Unlike the Europe-United States situation, however, China faces an ongoing currency mismatch leading to the syndrome of "conflicted virtue" (McKinnon and Schnabl 2004, and McKinnon 2005) that prevents private market makers from clearing the excess supply of dollars.

What causes the mismatch that undermines the case for floating? The renminbi, like the currencies of other developing economies, is not used significantly for international borrowing or lending; but China couples this gap in its capital markets with an enormous saving (trade) surplus. Thus dollar, rather than renminbi, claims on 
foreigners continually pile up within the economy. (The dollar is the "default" international money.) Natural private market makers such as Chinese banks-or even insurance companies and pension funds - all have their liabilities to depositors, policy holders, and so forth, denominated in renminbi. Thus, even if the yuan/dollar rate fluctuated only randomly, Chinese financial institutions would be exposed to too much exchange risk (relative to their limited capital) to allow dollar assets continually to pile up on their balance sheets. At some point, they would stop buying new dollar claims associated with the ongoing trade surplus. Consequently, a free float would result in an indefinite upward spiral of the renminbi against the dollar-with no well-defined balance point where Chinese financial institutions become sufficiently willing buyers of dollar assets to stop their further depreciation.

This third misconception is linked to the first. A floating but appreciating renminbi would not predictably reduce China's trade surplus, and dollars would continue to pour into the economy. On the other hand, if China was not a creditor country because foreign trade (net saving) was close to being balanced, then no substantial internal currency mismatch would exist and an uneasy float could be possible ${ }^{4}$.

However, the issue is somewhat broader. Suppose China did not have a chronic saving surplus, but its bond markets were still not well developed at different terms to maturity, and there were residual capital controls (as in most developing economies). Then forward markets for private hedging against currency risk becomes difficult to organize and expensive. So, willy nilly, if the government attempted to float the rate, it would soon be drawn back to smooth exchange fluctuations-if only at higher frequencies - in order to reduce the risks seen by exporters and importers. This "fear of floating” is well documented by Carmen Reinhart and Guillermo Calvo (2000 and 2002).

\footnotetext{
${ }^{4}$ The non feasibility of a pure float applies symmetrically to a chronic debtor economy whose debts are denominated in foreign currencies, say dollars, that continue to pile up from ongoing trade deficits. Again there is an internal currency mismatch where domestic foreign currency debtors are threatened with bankruptcy should the domestic currency depreciate - and the threat thereof could easily precipitate a run out of the domestic currency. This was the case in the great Asian crisis of 1997-98 as the five countries involved had run trade deficits for several years and built up large (private) dollar debts.
} 


\section{Toward a Credibly Fixed Exchange Rate}

Overcoming these three misconceptions about the exchange rate is crucial for stabilizing China's monetary system. For a developing country like China on the periphery of the dollar standard, the exchange rate is best considered just an extension of domestic monetary policy - and not an instrument of trade policy. This monetary approach to the exchange rate suggests that China should reset the yuan/dollar exchange rate and adjust domestic monetary policy through time to keep it stable, as was the case between 1995 and 2004, i.e., phase 2 in Figure 2.

What should this new rate be? The precise level of the new rate is much less important than having it credibly stable into the indefinite future. However, with the unfortunate recent history of bashing China to get the rate up, an international understanding or more formal agreement to end China bashing is now necessary for any new fix to be sufficiently credible to eliminate the one-way bet on future renminbi appreciation. If such an agreement were forthcoming "today" (mid-2008), the PBC should simply pick today's rate of 6.8 yuan per dollar as the central rate-within the conventional narrow band of \pm 0.3 percent - to be continued forward.

Ending China bashing through a political agreement is not as far fetched as it might first seem. After almost 25 years of Japan bashing to get the yen up, in April 1995 U.S. Treasury Secretary Robert Rubin announced a new "strong dollar policy", and Japan bashing ceased. The U.S. Federal Reserve Bank and Bank of Japan then intervened jointly several times in the summer of 1995 to quash any further appreciations of the yen. Although this strong dollar policy saved Japan from further deflationary ruin, it was just a ceiling on the yen and not a stable fix. Subsequent large fluctuations in the yen/dollar rate, when domestic holdings of dollar assets from Japan's being an international creditor are large, have destabilized the Japanese financial system and tightened its low interest rate liquidity trap. But this interest rate story is a digression for another time (McKinnon 2007b).

In the Chinese case, it would be sufficient to stabilize the renminbi if foreign pressure to appreciate ceased. Then the $\mathrm{PBC}$ itself could reset the yuan/dollar rate so as to eliminate the one way bet on ongoing appreciation. A massive outflow of private capital largely intermediated by Chinese banks, insurance companies, pension funds, and so 
forth, would surely follow as these institutions would be more than happy to diversify into foreign assets once the one-way bet was eliminated. With normal private sector financial international intermediation for China's huge current account surplus, the PBC could stop purchasing dollar assets on a large scale. Indeed, if the new capital outflow exceeded the current account surplus, the PBC might have to sell some of China's absurdly high dollar reserves to keep the renminbi fixed against the dollar at the newly reset rate. In any event, the PBC could regain control over the domestic money supply while reducing reserve requirements on domestic banks. Inflation would come down and the efficiency of domestic financial intermediation would improve. The credit crunch in U.S. financial markets would be eased as private capital flowed back to the United States.

Finally, once its domestic monetary and exchange rate system was stabilized, China could then proceed deliberately to reduce excess domestic saving relative to its huge domestic investment without worrying about exacerbating near-term inflation. But to analyze desirable long-term changes in China's tax, spending, and dividend policies would be a major exercise in public finance beyond the scope of this paper.

\section{References}

Calvo, Guillermo and Carmen Reinhart 2002: Fear of Floating. Quarterly Journal of Economics 117, 379-408.

Cline, William 2005: The United States as a Debtor Nation. Washington D.C. Institute for International Economics.

Dooley, Folkerts-Landau and Garber 2004: An Essay on the Revived Bretton-WoodsSystem. International Journal of Finance and Economics 4, 307-313.

Green, Stephen 2008: On the Ground (in China), Standard Chartered Bank, 11 February, 2008.

Goyal, Rishi, and Ronald McKinnon 2003):Japan's Negative Risk Premium in Interest Rates: The Liquidity Trap and Fall in Bank Lending. The World Economy, 26, 339363.

Hoffman, Andreas / Schnabl, Gunther 2008: Monetary Policy, Vagabonding Liquidity and Bursting Bubbles in New and Emerging Markets - An Overinvestment View. Forthcoming in The World Economy 31

McKinnon, Ronald 1981: Currency Substitution and Instability in the World Dollar Standard", American Economic Review 72, 3, 320-333.

McKinnon, Ronald 2005: Exchange Rates under the East Asian Dollar Standard: Living with Conflicted Virtue. MIT Press, Cambridge, Mass. 
McKinnon, Ronald 2007a: U.S. Current Account Deficits and the Dollar Standard's Sustainability: A Monetary Approach. CESifo Forum 4/2007, 12-23.

McKinnon, Ronald 2007b: Japan's Deflationary Hangover: Wage Stagnation and the Syndrome of the Ever-Weaker Yen. Singapore Economic Review 52, 3, 309-334

McKinnon, Ronald / Ohno, Kenichi 1997: Dollar and Yen. Resolving Economic Conflict between the United Stated and Japan. MIT Press. Cambridge Mass.

McKinnon, Ronald / Schnabl, Gunther 2004: A Return to Soft Dollar Pegging in East Asia? Mitigating Conflicted Virtue. International Finance 7, 2, 169-201.

Qiao, Hong 2007: Exchange Rates and Trade Balances under the Dollar Standard. Journal of Policy Modeling 29, 765-782.

Reinhart, Carmen 2000: The Mirage of Floating Exchange Rates. American Economic Review 90, 65-70.

Swoboda, Alexander 1978: Gold, Dollars, Euro-Dollars, and the World Money Stock under Fixed Exchange Rates. American Economic Review 68, 4, 625-642. 


\section{CESifo Working Paper Series}

for full list see www.cesifo-group.org/wp

(address: Poschingerstr. 5, 81679 Munich, Germany, office@cesifo.de)

2325 Helmuth Cremer, Philippe De Donder, Dario Maldonado and Pierre Pestieau, Forced Saving, Redistribution and Nonlinear Social Security Schemes, June 2008

2326 M. Hashem Pesaran and Paolo Zaffaroni, Optimal Asset Allocation with Factor Models for Large Portfolios, June 2008

2327 Harald Badinger and Peter Egger, Horizontal versus Vertical Interdependence in Multinational Activity, June 2008

2328 Jan K. Brueckner and Harris Selod, A Theory of Urban Squatting and Land-Tenure Formalization in Developing Countries, June 2008

2329 Paolo M. Panteghini, Corporate Debt, Hybrid Securities and the Effective Tax Rate, June 2008

2330 Guglielmo Maria Caporale, Juncal Cuñado and Luis A. Gil-Alana, Modelling Long-Run Trends and Cycles in Financial Time Series Data, June 2008

2331 Avi Ben-Bassat and Momi Dahan, Social Identity and Voter Turnout, June 2008

2332 Martin R. West and Ludger Wößmann, "Every Catholic Child in a Catholic School”: Historical Resistance to State Schooling, Contemporary Private Competition, and Student Achievement across Countries, June 2008

2333 Erkki Koskela and Panu Poutvaara, Outsourcing and Labor Taxation in Dual Labor Markets, June 2008

2334 Philippe Choné and Laurent Linnemer, Optimal Litigation Strategies with Signaling and Screening, June 2008

2335 Albert Solé-Ollé and Pilar Sorribas-Navarro, Does Partisan Alignment Affect the Electoral Reward of Intergovernmental Transfers?, June 2008

2336 Antonio Cabrales and Piero Gottardi, Markets for Information: Of Inefficient Firewalls and Efficient Monopolies, June 2008

2337 Sumon Majumdar and Sharun W. Mukand, The Leader as Catalyst - on Leadership and the Mechanics of Institutional Change, June 2008

2338 Ulrich Hange, Tax Competition, Elastic Labor Supply, and Growth, June 2008

2339 Guy Laroque and Bernard Salanié, Does Fertility Respond to Financial Incentives?, June 2008 
2340 Adriano Paggiaro, Enrico Rettore and Ugo Trivellato, The Effect of Extending the Duration of Eligibility in an Italian Labour Market Programme for Dismissed Workers, June 2008

2341 Helmut Seitz, Minimum Standards, Fixed Costs and Taxing Autonomy of Subnational Governments, June 2008

2342 Robert S. Chirinko, Leo de Haan and Elmer Sterken, Asset Price Shocks, Real Expenditures, and Financial Structure: A Multi-Country Analysis, July 2008

2343 Wolfgang Leininger, Evolutionarily Stable Preferences in Contests, July 2008

2344 Hartmut Egger and Udo Kreickemeier, Fairness, Trade, and Inequality, July 2008

2345 Ngo Van Long and Bodhisattva Sengupta, Yardstick Competition, Corruption, and Electoral Incentives, July 2008

2346 Florian Baumann, Employment Protection: The Case of Limited Enforceability, July 2008

2347 Alessandro Balestrino, Cinzia Ciardi and Claudio Mammini, On the Causes and Consequences of Divorce, July 2008

2348 Dirk Schindler and Benjamin Weigert, Insuring Educational Risk: Opportunities versus Income, July 2008

2349 Lammertjan Dam and Ben J. Heijdra, The Environmental and Macroeconomic Effects of Socially Responsible Investment, July 2008

2350 Avner Greif, Contract Enforcement and Institutions among the Maghribi Traders: Refuting Edwards and Ogilvie, July 2008

2351 Helmuth Cremer, Philippe De Donder, Dario Maldonado and Pierre Pestieau, Habit Formation and Labor Supply, July 2008

2352 Francesco Menoncin and Paolo M. Panteghini, The Johansson-Samuelson Theorem in General Equilibrium: A Rebuttal, July 2008

2353 Michael Kaganovich and Itzhak Zilcha, Alternative Social Security Systems and Growth, July 2008

2354 Keith Blackburn, Kyriakos C. Neanidis and M. Emranul Haque, Corruption, Seigniorage and Growth: Theory and Evidence, July 2008

2355 Edward Castronova, A Test of the Law of Demand in a Virtual World: Exploring the Petri Dish Approach to Social Science, July 2008

2356 Harald Badinger and Peter Egger, GM Estimation of Higher-Order Spatial Autoregressive Processes in Cross-Section Models with Heteroskedastic Disturbances, July 2008 
2357 Wolfgang Buchholz and Jan Schumacher, Discounting the Long-Distant Future: A Simple Explanation for the Weitzman-Gollier-Puzzle, July 2008

2358 Luca Anderlini, Leonardo Felli and Alessandro Riboni, Statute Law or Case Law?, July 2008

2359 Guglielmo Maria Caporale, Davide Ciferri and Alessandro Girardi, Are the Baltic Countries Ready to Adopt the Euro? A Generalised Purchasing Power Parity Approach, July 2008

2360 Erkki Koskela and Ronnie Schöb, Outsourcing of Unionized Firms and the Impacts of Labour Market Policy Reforms, July 2008

2361 Francisco Alvarez-Cuadrado and Ngo Van Long, A Permanent Income Version of the Relative Income Hypothesis, July 2008

2362 Gabrielle Demange, Robert Fenge and Silke Uebelmesser, Financing Higher Education and Labor Mobility, July 2008

2363 Alessandra Casarico and Alessandro Sommacal, Labor Income Taxation, Human Capital and Growth: The Role of Child Care, August 2008

2364 Antonis Adam, Manthos D. Delis and Pantelis Kammas, Fiscal Decentralization and Public Sector Efficiency: Evidence from OECD Countries, August 2008

2365 Stefan Voigt, The (Economic) Effects of Lay Participation in Courts - A Cross-Country Analysis, August 2008

2366 Tobias König and Andreas Wagener, (Post-)Materialist Attitudes and the Mix of Capital and Labour Taxation, August 2008

2367 Ximing Wu, Andreas Savvides and Thanasis Stengos, The Global Joint Distribution of Income and Health, August 2008

2368 Alejandro Donado and Klaus Wälde, Trade Unions Go Global!, August 2008

2369 Hans Gersbach and Hans Haller, Exit and Power in General Equilibrium, August 2008

2370 Jan P.A.M. Jacobs and Jan-Egbert Sturm, The Information Content of KOF Indicators on Swiss Current Account Data Revisions, August 2008

2371 Oliver Hülsewig, Johannes Mayr and Timo Wollmershäuser, Forecasting Euro Area Real GDP: Optimal Pooling of Information, August 2008

2372 Tigran Poghosyan and Jakob de Haan, Determinants of Cross-Border Bank Acquisitions in Transition Economies: A Latent Class Analysis, August 2008

2373 David Anthoff and Richard S.J. Tol, On International Equity Weights and National Decision Making on Climate Change, August 2008 
2374 Florian Englmaier and Arno Schmöller, Reserve Price Formation in Online Auctions, August 2008

2375 Karl Farmer, Birgit Friedl and Andreas Rainer, Effects of Unilateral Climate Policy on Terms of Trade, Capital Accumulation, and Welfare in a World Economy, August 2008

2376 Monika Bütler, Stefan Staubli and Maria Grazia Zito, The Role of the Annuity’s Value on the Decision (Not) to Annuitize: Evidence from a Large Policy Change, August 2008

2377 Inmaculada Martínez-Zarzoso, The Impact of Urbanization on $\mathrm{CO}_{2}$ Emissions: Evidence from Developing Countries, August 2008

2378 Brian Roberson and Dmitriy Kvasov, The Non-Constant-Sum Colonel Blotto Game, August 2008

2379 Ian Dew-Becker, How Much Sunlight Does it Take to Disinfect a Boardroom? A Short History of Executive Compensation Regulation, August 2008

2380 Cécile Aubert, Oliver Falck and Stephan Heblich, Subsidizing National Champions: An Evolutionary Perspective, August 2008

2381 Sebastian Buhai, Miguel Portela, Coen Teulings and Aico van Vuuren, Returns to Tenure or Seniority?, August 2008

2382 Erkki Koskela and Jan König, Flexible Outsourcing, Profit Sharing and Equilibrium Unemployment, August 2008

2383 Torberg Falch and Justina AV Fischer, Does a Generous Welfare State Crowd out Student Achievement? Panel Data Evidence from International Student Tests, September 2008

2384 Pedro Gomes and François Pouget, Corporate Tax Competition and the Decline of Public Investment, September 2008

2385 Marko Koethenbuerger, How Do Local Governments Decide on Public Policy in Fiscal Federalism? Tax vs. Expenditure Optimization, September 2008

2386 Ronald McKinnon and Gunther Schnabl, China’s Exchange Rate Impasse and the Weak U.S. Dollar, September 2008 